\title{
Higher Education - Importance and Funding in Slovenia
}

\author{
UDK: $378.014 .543(045)$
}

\author{
Maja Klun \\ University of Ljubljana, Faculty of Administration, Slovenia \\ maja.klun@fu.uni-lj.si
}

Marina Šućur

University of Ljubljana, Slovenia

marina.sucur@uni-lj.si

\begin{abstract}
Funding of education is becoming a particularly problematic issue, because public funding is no longer sufficient. The article considers the problems of funding higher education from the point of view of the sufficiency of funds and from the point of view of the importance of education. It illustrates methods of direct and indirect funding of education in Slovenia and presents the results of a survey in which students gave their opinions on the importance of education and on education funding. A large majority of respondents agree that the introduction of tuition fees would cause a reduction in participation in higher education and a consequent reduction in equal opportunities for education. Despite this, the largest share of respondents did not agree with the statement that in case of the introduction of tuition fees they would not enrol in education.
\end{abstract}

Key words: higher education, funding, importance of studying, Slovenia

JEL: A23, H52

\section{Introduction}

Education has long been considered an important social value. Providing education is the task of higher education institutions, which today are more accessible to a wider circle of people than they were in the past, and as a result the number of students is growing. Funding is becoming a particularly problematic issue. Public funding is no longer sufficient and 


\section{Maja Klun, Marina Šućur}

\section{Higher Education - Importance and Funding in Slovenia}

experts are increasingly calling for private funding of education alongside public funding, in the form of fees, loans, etc. Private funding undoubtedly contributes to ensuring a sufficiency of funds but it is questionable whether it guarantees equal opportunities for education. Furthermore, one of the reasons for public funding is that education does not only benefit the individual but, indirectly, the whole of society. The country needs educated people for economic growth and successful development. The interest of the individual, meanwhile, relates to expectations of future employment and earnings, quality of life, personal development, and so on.

The main problems facing higher education today are therefore the following: in most countries university funding is falling, since universities are funded through taxation, while concerns are being raised about quality. Financial aid for students is insufficient and the proportion of students from lower socioeconomic backgrounds is small. As a result, most of the beneficiaries are from wealthier families.

It has traditionally been the case in Europe that higher education institutions are mainly publicly funded. Although experts agree on the need to increase the participation of individuals in funding, the majority of the public has yet to be convinced of this. The limitations are mainly mental and social in nature, since it has always been considered the education should be free and equally accessible to people of all backgrounds. In most countries the right to free higher education is guaranteed by the constitution or by statute. Some research (Aghion et al., 2010) shows that an exogenous increase in a university's expenditure generates more output, if the university is more autonomous and faces more competition. According to the research by Del Rey and Racionero (2010) an income contingent loan with risk-pooling can induce the optimal level of student participation provided and at the same time it covers both financial costs of education and forgone earnings.

The article sets out the ways and forms of public funding of higher education, both the funding of institutions and the funding of students by means of direct or indirect forms of funding. This is followed by a presentation of the funds spent on education and a comparison with EU Member States. The final part of the article contains the results of an extensive survey among students on their views of the importance of higher education and its funding. 


\section{The importance of higher education and its funding}

Many people place education in the category of mixed (or quasi-public) goods which are private in terms of consumption, while their provision is in the public interest (public funding and/or public provision). Higher education thus brings benefits both to the individual and to the wider environment (co-benefits or externalities). The main problem is measuring the actual scale of these benefits. It is not possible to measure them according to a single scale, if indeed it is possible to measure them at all (Vossensteyn, 2004). Bevc et al. (2001, p.13) believe that in the case of higher education the question is whether mass higher education is primarily an individual good or primarily a social good, or in other words whether it is society or those in education who receive greater benefit from the education. As long as the number of those enrolled in the education remains small, this is not an important question from the point of view of expenditure. Later, however, the increase in state expenditure needs to be justified from the point of view either of fairness or of efficiency. It is estimated that the greater the number of people receiving the benefits of higher education (they hold a higher education qualification), the greater the relative inequality of those who do not have a higher education qualification. We can therefore say that higher education (full-time study) is a public good to the extent to which the state is willing and able to fund it.

Demand for higher education usually increases in periods of economic crisis. Individuals unable to find employment or with few possibilities of finding employment see higher education as a way to improve their employment prospects. However, a large number of graduates have the effect of increasing the supply of a highly qualified workforce, with a consequent reduction of the cost of the workforce. This raises the question of whether it is still possible to talk about the benefits that an individual is supposed to derive from higher education. In 2008, Greek university students protesting against the country's education system dubbed themselves the '700-euro generation', since despite their higher education qualifications they were unable to obtain better paid employment.

There are thus several sides to the public funding of higher education. The fact that higher education graduates are more difficult to employ also places pressure on social expenditure and no longer brings only benefits. Judging from the annual report of the Employment Service of Slovenia (ESS), level of education, which in the past played a major role in terms of employment 
Maja Klun, Marina Šućur

Higher Education - Importance and Funding in Slovenia

opportunities, is today for the most part no longer so important (ESS, 2009). The largest group of the unemployed still consists of people with the lowest level of educational qualifications. In 2009 they accounted, on average, for $39.4 \%$ of the registered unemployed. Those with level 6 or 7 qualifications or higher accounted for $10 \%$ of the registered unemployed in 2009 , although in recent years the share of this group has grown more than that of the other groups.

\section{Direct and indirect funding of higher education in Slovenia}

The system of funding higher education in Slovenia is characterised by the fact that it relies predominantly on public funds. State funds are received both by educational establishments and by students. Private higher education institutions which have been granted a concession to provide a public service are also recipients of state funds for education.

The method of funding higher education in Slovenia is regulated by the Higher Education Act (ZViS), specifically by Chapter 8 (Articles 72-78). Under this Act, funds for the activity of higher education institutions are defined in the national budget, taking into account the field of study and the number of enrolled students and graduates of full-time first- and second-cycle study. The Act envisages the more detailed regulation of funding by means of a special regulation adopted by the Government of the Republic of Slovenia. The funding of higher education institutions is thus regulated in more detail by the Decree on the budgetary financing of higher education and other university member institutions from 2004 to 2008. In this period the Decree was amended four times, most recently in October 2008 with the adoption of the Decree amending the Decree on the budgetary financing of higher education and other university member institutions from 2004 to 2008, which extended the validity of the current funding method to 2009. A new decree is currently in preparation for the next period, from 2010 onwards, although in terms of the stability of funding of this area it would be better if it were regulated by law (as envisaged by the Constitution of the Republic of Slovenia).

Direct state financial aid for students in Slovenia only exists in the form of scholarships, which are limited to particularly gifted candidates (Zois scholarships) and those from low-income families (state scholarships). The new 


\section{Higher Education - Importance and Funding in Slovenia}

Scholarships Act envisages the co-financing of corporate scholarships for the purpose of increasing their number. A system of state-supported student loans has yet to be developed. Students can take out student loans with banks, but these are not purpose-specific loans (the purpose of use is not known).

Scholarships are regulated by the Scholarship Act (Zštip, OJ RS, No 59/2007). This Act defines scholarships as a supplementary receipt intended to cover costs relating to education (Article 5). Article 9 sets out the general conditions for obtaining a scholarship: 'Under this Act a scholarship may be obtained by beneficiaries who on first enrolment in the first year of further education or higher education or on first enrolment in the first, second or third cycle of education are under 26 years old and:

- are not simultaneously receiving any of the scholarships from article 5 of this Act,

- are not in receipt of a scholarship or other educational allowances under other regulations,

- are not in an employment relationship and do not perform an independent registered activity,

- $\quad$ are not registered as unemployed at the Employment Service of Slovenia (hereinafter: ESS).'

Article 13 of the ZViS was amended by the Act amending the Scholarships Act (Zštip-A, OJ RS, No 40/2009). It provides that state scholarships shall be granted to candidates who fulfil the general conditions from this Act and in whose case the average monthly income per family member in the past calendar year before submitting the application does not exceed 65\% (before the amendment this threshold was $60 \%$ ) of the minimum wage per family member in the same period for those candidates studying in their place of permanent residence, and from $66 \%$ to $68 \%$ (before the amendment the threshold was from $60 \%$ to $65 \%$ ) of the minimum wage per family member for those candidates studying in a place other than their place of permanent residence.

Under Article 24 of the Zštip, a Zois scholarship may be obtained by a student who fulfils the general conditions and:

- has an average grade of at least 8.5 in further or higher education

- or is among the top $5 \%$ of students in his or her year group in terms of the average grade, or 


\section{Maja Klun, Marina Šućur}

\section{Higher Education - Importance and Funding in Slovenia}

- has exhibited outstanding achievements in an individual social sphere, irrespective of the year of education.

As already mentioned, the state also provides funds for indirect aid for students. Rules for subsidising meals were not laid down until 1996, with the adoption of the first administrative-legal act in this field, namely the Decree on subsidising student meals (OJ RS, No 24/1996). The Subsidising of Student Meals Act (ZSšP, OJ RS, No 85/2002) was adopted in 2002. Under this Act (article 6), 'All those who hold the status of student and who are not in employment' are entitled to subsidised student meals. Unlike scholarships, all students are entitled to subsidised meals, regardless of their socio-economic background. The Rules on subsidising student meals (OJ RS, No 70/2007), however, define beneficiaries in more detail, specifying that they are both full-time and part-time students who are neither in employment nor registered at the ESS as jobseekers. The subsidising of food takes place in the form of meal vouchers. Each individual is entitled to one subsidised meal per working day, except during the school holidays (from 10 July to 20 August).

The subsidising of student accommodation is prescribed by the ZViS, which sets out the relevant selection criteria: academic success, financial situation, distance of place of permanent residents from place of study, and the social and health conditions of the student. More detailed provisions are set out in the Rules on subsidising student accommodation (OJ RS, No 22/2001). These rules also set out the scoring system for the above selection criteria. The subsidy amounts to at least $20 \%$ of the average monthly cost of accommodation. Students may also claim the subsidy for private rented accommodation. The Rules set out the minimum standard which must be guaranteed by halls of residence and private providers of student accommodation. The cost of accommodation in halls of residence or private rented accommodation is reduced by the amount of the subsidy.

The subsidising of transport is also prescribed by the ZViS. Students studying five kilometres or more from their place of permanent residence are entitled to a subsidy. The minimum subsidy is defined as $7 \%$ of the cost of a monthly travel card. The amount of the subsidy depends on socioeconomic status and distance from the place of study. Subsidies are regulated in more detail in the Rules on subsidising student transport (OJ RS, No 18/2004). The Rules divide the level of subsidy into four classes with regard to the gross monthly income per family member as a percentage of 
the gross average wage per employee in the Republic of Slovenia. The level of the subsidy in each class increases by $10 \%$ where the place of study is between 40 and 60 kilometres from the student's place of permanent residence, and by $20 \%$ where the place of study is over 60 kilometres from the student's place of permanent residence. Transport costs may be additionally covered within the context of scholarships. Urban passenger transport is subsidised by the municipality.

Student health care (insurance) is regulated by the Health Care and Health Insurance Act (ZZVZZ-UPB3, OJ RS, No 72/2006). On the basis of this Act, students are entitled to all health care services until the completion of full-time education (Article 22). The Act amending the Health Care and Health Insurance Act (ZZVZZ-K, OJ RS, No 76/2008), however, limited the entitlement to health insurance to persons in education up to the age of 26.

Tax reliefs for students and their parents are set out in the Income Tax Act (ZDoh-2, OJ RS, No 117/2006). General relief is granted to a resident on condition that no one else has claimed special relief for a dependent family member on his behalf (Article 111). This means that those students whose parents have not claimed them as dependent family members are entitled to general tax relief. Special tax relief may therefore be claimed by parents with dependent family members enrolled in education, but the size of the relief also depends on the number of dependent family members and is set out in Article 114 of the ZDoh-2. Article 113(3) of the ZDoh-2 provides for a special personal tax relief for residents who are in education (i.e. who have student status, but only up to the age of 26) and who perform temporary or occasional work on the basis of a referral from an authorised organisation. Once a year the amounts of the reliefs are coordinated with the consumer price growth coefficient for November of the current year compared to November of the previous year, according to figures from SURS, the national statistics office (Article 118 of the ZDoh-2). Relief also applies to 10\% of standard costs from students' income via referrals, which do not need to be shown separately.

The parents of students are also entitled to child allowance, which is a supplementary benefit for the maintenance, upbringing and education of a child, where the income per family member does not exceed $99 \%$ of the average wage in the Republic of Slovenia in the previous calendar year. The right to child allowance is defined in Article 57 of the Parental Care and Family Benefits Act ZSDP-UPB2, OJ RS, No 110/2006). Parents may claim 
Maja Klun, Marina Šućur

Higher Education - Importance and Funding in Slovenia

this right until the child reaches the age of 18 or, if he or she has student status, until the age of 26 (or older, in exceptional cases).

\section{Public expenditure on higher education}

The costs of full-time study in Slovenia are entirely covered by public funds, since educational establishments receive state funds for the implementation of full-time undergraduate programmes or the first and second Bologna cycles (the payment of fees for full-time study is prohibited by the ZViS). Part-time study is funded from private sources (a contribution from the students and their parents or employers), by the payment of fees in the amount of total teaching costs per student.

Public expenditure of the state and municipalities on formal education in Slovenia amounted in 2007 to 1,795 million euros or $5.21 \%$ of GDP, including $1.21 \%$ for tertiary education, which represented under a fifth $(18 \%)$ of all public expenditure on education. The state devoted just under $28 \%$ of all funds for formal education to tertiary education, while municipalities earmarked just 3\% for secondary and tertiary education together (SURS, 2009).

Of the state and municipal budget funds earmarked for formal education, 92\% were destined for educational establishments, while transfers to households and funds for other private entities accounted for $8 \%$. Of the above $92 \%$ of funds for educational establishments, just under $20 \%$ (or 323 million euros) were intended for tertiary education, with both the share and the amount of these funds having fallen. On the other hand, the majority (almost two thirds) of public transfers were intended for tertiary education. Within the structure of all public expenditure on tertiary education in 2007, transfers for households and other private entities together represented under a quarter of the total public expenditure (SURS, 2009).

As stated above, the state helps cover the living costs of students through subsidies to households. The business and industrial sector contributes to covering living costs through corporate scholarships, although these represent a small share within the overall scholarship system (just over a tenth of all scholarships granted). According to figures from SURS for 2007, the total number of scholarship holders (students in secondary and tertiary education) is falling, with just over a quarter receiving a 
scholarship, with the result that the biggest burden of living costs is borne by students and their parents (although the share of these costs is difficult to measure because of the differing circumstances and needs of individuals).

Of the EU Member States, 16 states charge tuition fees and 13 charge enrolment fees. Within the EU a trend towards charging tuition fees for full-time study in public institutions can be observed. Some countries have introduced tuition fees in recent years, while others are debating their introduction. In most cases tuition fees for full-time study are set by the state and, in the EU, range from 200 to 1000 euros. Enrolment fees in the EU are generally below 200 euros. In 15 EU countries, students pay for studies that extend beyond the official length of the programme, while in nine countries students only pay in this case (Eurostat, 2007; in: Bevc, 2008, 9). The Eurostat publication on key higher education indicators in Europe cites Slovenia as the only example of an opposite trend.

In terms of public expenditure on education as a share of GDP in 2006, Slovenia occupied eighth place (among all EU Member States) in terms of share of public expenditure on tertiary education. The share of funds destined for tertiary education in EU countries is shown in the table on the next page.

The share of state subsidies to students, households and other private entities in OECD countries in 2005 amounted on average to $18 \%$ of total public expenditure on higher education (less than in 2007 in Slovenia). Norway and New Zealand were well above the OECD average, with subsidies accounting for over $40 \%$ of total public expenditure on higher education in 2005 (Highlights from Education at a Glance, 2008, 60). In comparison with the OECD average, the share of private expenditure in Slovenia is slightly lower. A downwards trend in the share of public expenditure for higher education establishments may be observed in OECD countries, while the share of private expenditure increased by $6 \%$ between 1995 and 2005, in the latter year reaching $27 \%$ of total expenditure for higher education establishments (Highlights from Education at a Glance, 2008, 58). 
Maja Klun, Marina Šućur

Higher Education - Importance and Funding in Slovenia

Table 1: Public expenditure on tertiary education as a share of GDP (\%)

\begin{tabular}{|c|c|c|c|}
\hline \multirow[t]{2}{*}{ Country } & \multicolumn{3}{|c|}{ Year } \\
\hline & 2004 & 2005 & 2006 \\
\hline EU-27 & 1.13 & 1.15 & 1.13 \\
\hline Belgium & 1.29 & 1.29 & 1.32 \\
\hline Bulgaria & 0.80 & 0.76 & 0.73 \\
\hline Czech Republic & 0.94 & 0.89 & 1.23 \\
\hline Denmark & 2.51 & 2.38 & 2.27 \\
\hline Germany & 1.16 & 1.14 & 1.11 \\
\hline Estonia & 0.86 & 0.93 & 0.92 \\
\hline Ireland & 1.10 & 1.11 & 1.14 \\
\hline Greece & 1.32 & 1.44 & - \\
\hline Spain & 0.97 & 0.95 & 0.95 \\
\hline France & 1.21 & 1.19 & 1.19 \\
\hline Italy & 0.77 & 0.76 & 0.80 \\
\hline Cyprus & 1.48 & 1.58 & 1.65 \\
\hline Latvia & 0.68 & 0.88 & 0.91 \\
\hline Lithuania & 1.06 & 1.03 & 1.00 \\
\hline Luxembourg & - & - & - \\
\hline Hungary & 1.02 & 1.03 & 1.04 \\
\hline Malta & 0.53 & 1.06 & - \\
\hline Netherlands & 1.45 & 1.47 & 1.50 \\
\hline Austria & 1.44 & 1.49 & 1.48 \\
\hline Poland & 1.15 & 1.19 & 0.96 \\
\hline Portugal & 0.83 & 0.98 & 1.00 \\
\hline Romania & 0.70 & 0.81 & - \\
\hline Slovenia & 1.31 & 1.25 & 1.24 \\
\hline Slovakia & 0.98 & 0.81 & 0.90 \\
\hline Finland & 2.07 & 2.01 & 1.94 \\
\hline Sweden & 2.04 & 1.92 & 1.84 \\
\hline United Kingdom & 1.00 & 1.20 & 1.10 \\
\hline
\end{tabular}

Source: Eurostat, 2010

- figure unavailable 


\section{Higher Education - Importance and Funding in Slovenia}

\section{Research procedure}

\subsection{Research method and sample}

A survey was conducted to assess the importance of higher education and its funding from the point of view of students. The questions and statements were formulated on the basis of theoretical findings and the opinions of experts in this field. A questionnaire was prepared using the web-based survey tool SurveyMonkey (www.surveymonkey.com). A link to the questionnaire was posted on student forums. Students took part in the survey between 28 May 2009 and 30 June 2009. In order to submit the questionnaire it was necessary to answer all the questions, which means that only completed questionnaires were taken into account in the analysis. Only one answer was possible for each question. A total of 400 students from various universities and independent higher education institutions in Slovenia took part in the survey.

The survey consisted of two parts. The first part contained general data about the respondents. In the second part, respondents answered questions about higher education and its funding and rated 16 statements on a scale of 1 to 4 , where the ratings had the following meaning: 1 - strongly disagree, 2 disagree, 3 - agree, 4 - strongly agree. The scale was deliberately designed with an even number of possible responses, which means that every respondent had to give an opinion, or in other words that there was no middle response signifying 'neither agree nor disagree'.

More women $(62 \%)$ than men (38\%) completed the questionnaire. The largest number of respondents were aged 23 and 24 (16\% in both cases). The vast majority of respondents were undergraduate or first-cycle students (95\%), with just $5 \%$ studying at postgraduate or second-cycle level. The majority of respondents $(80 \%)$ were enrolled in full-time study, with the remainder studying part time. The largest share (35\%) was represented by absolvent students. With regard to the structure of the sample, it may be said that it did not deviate significantly from the structure of the overall population. According to SURS figures for $2008,59.7 \%$ of those enrolled in higher education were women, the share of part-time students was $27.4 \%$, the share of absolvent students was $19.3 \%$, and $88.2 \%$ of students were enrolled in undergraduate or first-cycle programmes. 
Maja Klun, Marina Šućur

Higher Education - Importance and Funding in Slovenia

\subsection{Analysis of the results of the survey}

This section presents the survey results relating to students' reasons for studying and their opinions regarding funding. Graph 1 contains the students' answers regarding their reasons for studying at the higher education level. Most students (32\%) believe that a higher education qualification will enable them to get a better job. A slightly smaller percentage $(29 \%)$ believe that they will have more chance of finding a job after completing their studies. Desire for knowledge was the reason given by $27 \%$ of respondents. No one cited failure to find employment as their reason for continuing education at the higher education level.

\section{Graph 1: Reasons for studying}

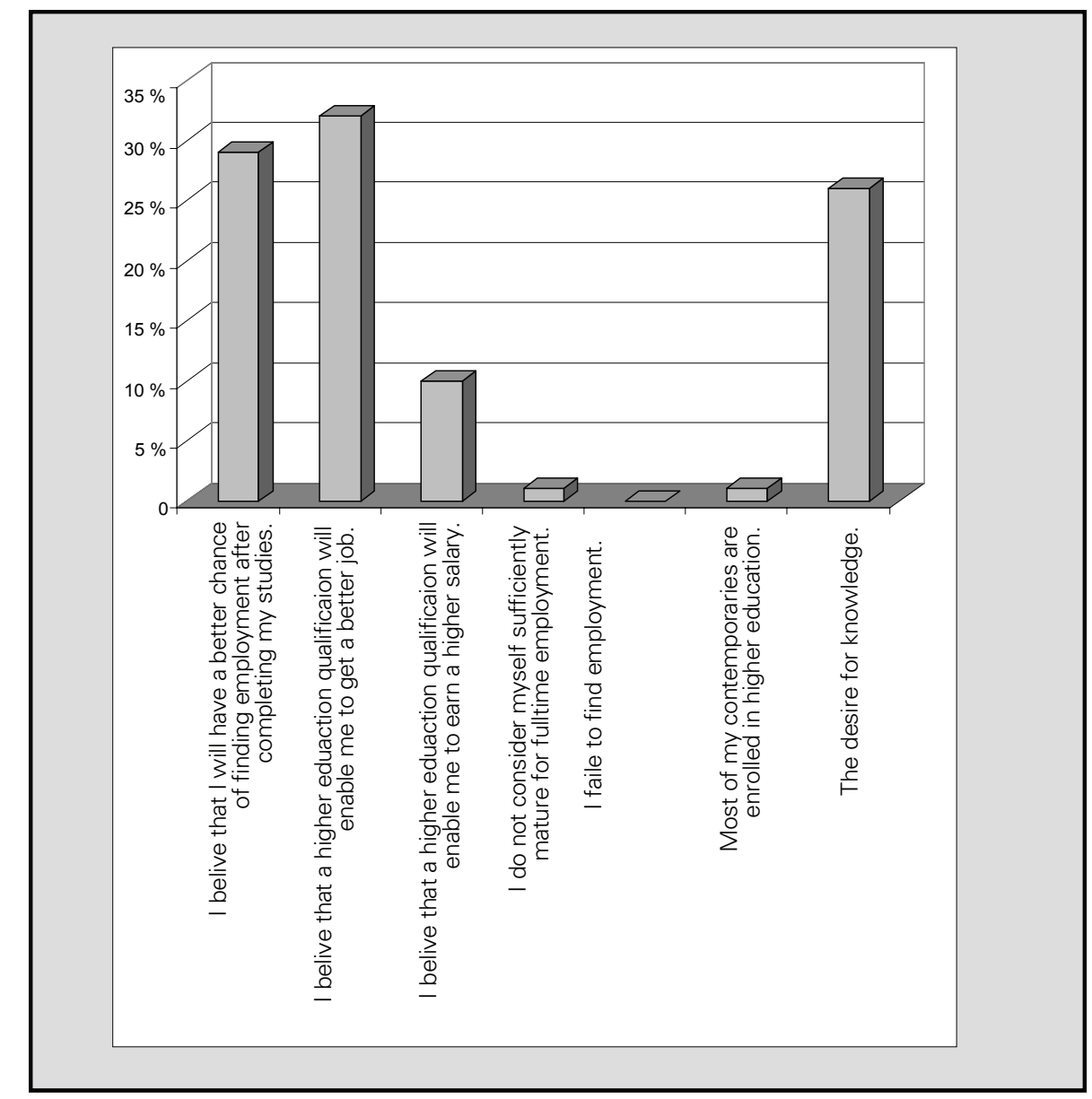

Source: Survey 
With regards to the funding of higher education, the majority of respondents $(68 \%)$ were of the opinion that higher education is a public good and should therefore be free, while $30 \%$ of respondents believed that higher education benefits both society and the individual, and that therefore the costs of education should be shared. Only $2 \%$ of respondents believed that the main benefit of higher education is to the individual and that it is therefore the individual who should cover the costs of higher education.

Table 2 contains 16 statements from the survey and the average level of agreement of the respondents with each of them. As already stated, the scale of agreement was from 1 to 4 , so the average levels of agreement are also within this scale. Thus an average agreement of less than 2.5 means that the majority of respondents did not agree with the statement, while an average agreement of over 2.5 means that the majority of respondents did agree with the statement. The closer the average agreement is to 2.5 , the more the opinion of respondents is divided. Respondents agreed most with the statement that state-supported loans should include incentives for students. A large share of respondents also believed that the introduction of tuition fees would reduce equal opportunities for education and that the introduction of fees would cause a reduction in participation in higher education.

Respondents agreed least with the statement that in the case of the introduction of tuition fees they would not enrol in education, given that higher qualifications have no effect on earnings. We may therefore conclude that they would be prepared to invest in education, since they expect a financial benefit from it in the future. Respondents were also of the opinion that despite the fact that higher education was free and despite the large proportion of the population studying at the higher education level and also completing studies at this level, education nevertheless meant better opportunities when seeking employment. A majority also disagreed with the statement that, in the case of tuition fees, higher education establishments would focus more on quality and the efficiency of implementation of programmes.

Respondents were most divided with regard to the possibility of paying tuition fees by means of student loans. Half the respondents did not agree with this statement, while the other half would decide not to study in the case of the introduction of tuition fees, for fear of being in debt. The opinion of respondents was also divided with regard to the statement that in the case of the introduction of tuition fees, only those with a serious intention to study would enrol. Respondents also disagreed as to whether charging tuition fees for part-time study was discriminatory. 
Maja Klun, Marina Šućur

Higher Education - Importance and Funding in Slovenia

Table 2: Average level of agreement with statements

\begin{tabular}{|c|c|}
\hline & $\begin{array}{c}\text { average } \\
\text { agreement }\end{array}$ \\
\hline $\begin{array}{l}\text { The state is not capable of funding increased take-up of higher education in the } \\
\text { traditional way (i.e. from public funds). }\end{array}$ & 2.42 \\
\hline $\begin{array}{l}\text { The state should devote more funds to direct forms of aid (scholarships, stu- } \\
\text { dent loans) than to indirect forms (subsidies for meals, transport, accommoda- } \\
\text { tion, etc.). }\end{array}$ & 3.01 \\
\hline $\begin{array}{l}\text { The payment of tuition fees for part-time study is discriminatory in comparison } \\
\text { to free full-time study. }\end{array}$ & 2.46 \\
\hline $\begin{array}{l}\text { Students would be more motivated to study if they had to cover part of the } \\
\text { costs of studying themselves. }\end{array}$ & 2.77 \\
\hline The introduction of tuition fees would reduce participation in higher education. & 3.27 \\
\hline The introduction of tuition fees would reduce equal opportunities for education. & 3.37 \\
\hline $\begin{array}{l}\text { In the case of the introduction of tuition fees, only those with a serious inten- } \\
\text { tion to study would enrol. }\end{array}$ & 2.55 \\
\hline $\begin{array}{l}\text { Tuition fees would contribute to reducing the duration of studies and increasing } \\
\text { the rate of progress through the programme (fewer repeated years). }\end{array}$ & 2.69 \\
\hline $\begin{array}{l}\text { I would be willing to repay my tuition fees but only after completing my studies } \\
\text { (in instalments and provided I am in a sufficiently well-paid job). }\end{array}$ & 2.63 \\
\hline $\begin{array}{l}\text { The amount of repayment of student loans should be linked to the earnings of } \\
\text { the graduate. }\end{array}$ & 2.69 \\
\hline $\begin{array}{l}\text { If tuition fees and the possibility of repaying them via student loans were intro- } \\
\text { duced, I would decide not to study for fear of future debt. }\end{array}$ & 2.48 \\
\hline $\begin{array}{l}\text { Even if I had to pay tuition fees, I would still enrol in education and, if neces- } \\
\text { sary, get into debt, because I believe that with a higher education qualification I } \\
\text { will have more chance of finding a better (and better paid) job. }\end{array}$ & 2.93 \\
\hline $\begin{array}{l}\text { State-supported loans should contain incentives for students (e.g. reduction of } \\
\text { the loan debt if studies are completed within the prescribed period). }\end{array}$ & 3.41 \\
\hline $\begin{array}{l}\text { If higher education institutions were able to charge tuition fees, they would } \\
\text { focus more on quality and the efficiency of implementation of programmes. }\end{array}$ & 2.31 \\
\hline $\begin{array}{l}\text { If I had to pay tuition fees I would not enrol in education because I believe that } \\
\text { higher qualifications have no effect on earnings, }\end{array}$ & 1.72 \\
\hline $\begin{array}{l}\text { Given that studying is free, the majority of people study and also complete } \\
\text { their studies, with the result that education does not bring better employment } \\
\text { prospects. }\end{array}$ & 2.16 \\
\hline
\end{tabular}

Source: Survey 


\section{Higher Education - Importance and Funding in Slovenia}

Answers did not differ significantly by gender, nor did they deviate from the overall average. Male respondents cited desire for knowledge as the main reason for studying. The respondents who were of the opinion that higher education benefits individuals, and that they should therefore cover the costs themselves, were for the most part men.

With regard to the type of study, greater differences and deviations from the average were noted, in particular in the case of postgraduate students. Half of the postgraduate students questioned $(50 \%)$ gave desire for knowledge as their reason for studying, while $64 \%$ were of the opinion that society and the individual should share the costs of education. A very large share of postgraduate students (82\%) intended to complete their studies within the envisaged duration. There were also considerable deviations from the overall average in the case of average agreement with statements, although opposing opinions were not expressed.

With regard to year of study, answers only differed in the case of the statement with regard to which there was least agreement among the overall population. Students from the third year onwards (excluding "absolvent" students) do not agree with the statement that they would decide not to study if they were required to repay tuition fees in the future. Students of the first and second years, on the other hand, agree with this statement and in the case of tuition fees would decide not to study for fear of future debt.

We have also analysed the answers in terms of the type of study. Deviations from the average were apparent above all on the part of part-time students. Half of part-time students (50\%) believed that society and the individual should share the costs of education. This percentage is not surprising, since part-time students pay for their own studies. Similarly, a considerably larger share of part-time students $(65 \%)$ intended to complete their studies within the envisaged duration. Their opinion differed from the overall average in terms of agreement with the statement that the state is not capable of funding increased take-up of higher education in the traditional way. As expected, and in contrast to the overall average, they also agreed with the statement that the payment of tuition fees for part-time study is discriminatory in comparison to free full-time study. 


\section{Maja Klun, Marina Šućur}

\section{Higher Education - Importance and Funding in Slovenia}

\section{Conclusion}

Tuition fees remain a 'taboo' topic, even though in the event of the introduction of tuition fees these would not necessarily have to cover the entire cost of education. Experts in fact advocate the introduction of tuition fees to cover between $20 \%$ and $30 \%$ of education costs. A large majority of respondents agree that the introduction of tuition fees would result in lower participation in higher education and that equal opportunities for education would therefore be reduced. Even so, the largest share of respondents did not agree with the statement that in the case of payment of tuition fees they would not enrol in education, given that higher qualifications have no effect on earnings. In other words, they would nevertheless be prepared to pay tuition fees in the expectation of future benefits, above all financial. New conditions in higher education (growing participation, the Bologna system) are dictating an adaptation of the system of funding. Experts warn that a lack of funds can lead to a fall in the quality of services. Despite this, respondents doubt that an increase of resources, above all private resources, would result in higher education establishments focusing more on quality and the efficiency of implementation of study programmes.

In the light of the increasing participation of individuals in the funding of higher education, it would make sense in Slovenia to consider the introduction of 'interest' payments for those students who do not complete their studies within the official programme duration. All changes cause a certain amount of dissatisfaction. Discussions and coordination of different interests are necessary. In view of the fact that students agreed most with the statement that state-supported loans should contain incentives for students, e.g. a reduction of the loan debt if studies are completed on schedule, we may conclude that they are in favour of incentives for completing studies within a specific time. Studying would therefore be free for those who complete their study obligations in good time. This would also ensure a greater rate of progress through study programmes and a lower dropout rate, since the results of the survey also confirmed the statistic that only half of all students complete their studies within the prescribed period.

Changes are urgently necessary in the field of higher education. All figures indicate that the funding system will be unsustainable in the long term, despite shrinking generations. On the other hand, both experts and students believe that the current funding method does not encourage students to complete 
Maja Klun, Marina Šućur

Higher Education - Importance and Funding in Slovenia

their studies within the envisaged time. Reform processes will therefore be necessary in the future.

Dr. Maja Klun is assistant professor at Faculty of Administration. Her main research fields are taxation, performance budgeting and performance measurement in public sector.

Marina Šucur graduated from the Faculty of Admi-nistration. Due to her considerable academic achievements in the Academic Years 2004-05, 2005-06 and 2007-08, she was appointed the most succes-sful student of her class. What is more, in the Academic Year 2008-09, she received the Award as the most successful graduate student of the Administration University Programme and the Faculty Prešeren Prize for the diploma titled "Financing of Higher Education". Currently, she works at the University of Ljubljana, in the University Office for the 1st and 2nd Degree, as an independent advisor for Joint Programmes. 


\section{Maja Klun, Marina Šućur Higher Education - Importance and Funding in Slovenia}

\section{References}

- Aghion P., Dewatripont M., Hoxby C., Mas-Colell A. and Sapir A. (2010). The governance and performance of universities: evidence from Europe and the US. Economic Policy, 7-59.

- Bevc M, Stanovnik T., Prevolnik-Rupel V. (2001). Analiza pravičnosti državnega financiranja izobraževanja v Sloveniji in možnosti za njeno povečanje. Ljubljana: Inštitut za ekonomska raziskovanja.

- Bevc, M. (2008). Financiranje, učinkovitost in pravičnost visokega izobraževanja - povezave med temi pojavi in mednarodna konferenca o njih. IB revija, (42), 5-18.

- Del Rey E., Racionero Ma. (2010). Financing schemes for higher education. European Journal of Political Economy, (26), 104-113.

- $\quad$ Eurostat. (2010). Statistics - Education and Training. Retrieved 14. 5. 2010 from Eurostat: http://epp.eurostat.ec.europa.eu/portal/page/portal/education/data/database

- $\quad$ OECD (2009). Highlights from Education at a Glance 2008. Retrieved 20. 9. 2009 from: »http://browse.oecdbookshop.org/oecd/pdfs/browseit/9609011E.PDF«.

- Pravilnik o subvencioniranju bivanja študentov. Uradni list RS, št. 22/2001.

- Pravilnik o subvencioniranju prevozov študentov. Uradni list RS, št. 18/2004.

- $\quad$ Pravilnik o subvencioniranju študentske prehrane. Uradni list RS, št. 70/2007.

- Statistični urad Republike Slovenije (2007). Štipendisti, Slovenija, 2007, začasni podatki. Retrieved 19. 8. 2008 from: http://www.stat.si/novica_prikazi.aspx?ID=1789

- SURS 2009, Izobraževanje. Statistične informacije, št. 32. Retrieved 14. 5. 2010 from: http://www.stat.si/doc/statinf/09-SI-200-0901.pdf

- Uredba o javnem financiranju visokošolskih in drugih zavodov, članic univerz, od leta 2004 do leta 2008. Uradni list RS, št. 134/2003.

- Uredba o spremembah in dopolnitvah Uredbe o javnem financiranju visokošolskih in drugih zavodov, članic univerz, od leta 2004 do leta 2008. Uradni list RS, št. 99/2008.

- Vossensteyn, H. (2004). Fiscal Stress: Worldwide Trends In Higher Education Finance. NASFAA Journal of Student Financial Aid, (34)1, Retrieved 10.2.2009 from: »http://www.nasfaa.org/annualpubs/journal/vol34n1/vossensteyn.pdf«. 10. 2. 2009.

- Zakon o dohodnini. Uradni list RS, št. 117/2006.

- Zakon o spremembah in dopolnitvah Zakona o štipendiranju. Uradni list, RS št. 40/2009.

- Zakon o spremembah in dopolnitvah Zakona o zdravstvenem varstvu in zdravstvenem zavarovanju. Uradni list RS, št. 76/2008.

- Zakon o starševskem varstvu in družinskih prejemkih (UPB2), Uradni list RS, št. $110 / 2006$. 


\section{Higher Education - Importance and Funding in Slovenia}

- Zakon o subvencioniranju študentske prehrane (UPB1). Uradni list RS, št. 74/2007.

- Zakon o štipendiranju. Uradni list RS, št. 59/2007.

- Zakon o visokem šolstvu (UPB3). Uradni list RS, št. 119/2006.

- Zakon o zdravstvenem varstvu in zdravstvenem zavarovanju (UPB3). Uradni list RS, št. 72/2006

- Zavod Republike Slovenije za zaposlovanje (2010). Letno poročilo 2009. Retrieved 14. 5. 2010 from: http://www.ess.gov.si/slo/Predstavitev/LetnaPorocila/lp09/LETNO\% 20POROCILO\%20ZRSZ\%202009.pdf 